BABELAO 2 (2013), p. 159-171

(C) ABELAO (Belgium)

\title{
About Georgian Fairytales
}

By

Elene Gogiashvili

Ivane Javakhishvili Tbilisi State University, Tbilisi

very fairytale can be defined as a journey of the hero.
Moreover, every fairytale tells something about its own
journey through the centuries.

Information about the Georgian fairytales in the oldest sources.

The term zghapari

Some old written sources mention Georgian folk tales, including translations of the Bible from $5^{\text {th }}-7^{\text {th }}$ centuries and the original Georgian hagiographies and secular literature of the Middle Ages. The term zghapari, the Georgian word for fairytale, translates "lie" and "fictitious story". "It was but it was nothing" - so reads the traditional beginning of Georgian fairytales. Zghapari connoting "a fictitious story" is used in Georgian

1 E. VIRSALADZE, "Zghapari” (Fairytale), in Kartuli khalkhuri poeturi shemokmedeba (Georgian folk poetry), Tbilisi, 1960, p. 366-369. 
hagiographic literature with the negative meaning in contrast to the factual report. This tendency of the negative meaning of zghapari continues through the Middle Ages until to the seventeenth century. The Georgian writer and lexicographer Sulkhan-Saba Orbeliani (1658-1725) defines the term zghapari as a fictitious lie, handed down in the form of a story. The other Georgian terms for the oral prose genres are ambavi and araki, meaning "a story". The negative connotations of zghapari through the Middle Ages stems from theological differences between Christianity and paganism.

\section{The first fixed Georgian fairytales}

Georgian fairytales were first recorded by the Italian catholic missionary Bernarde from Napoli who travelled Georgia between 1670 and 1680. Among the papers in his archive at Torre del Greco twelve Georgian fairytales were discovered and subsequently published in Georgia in $1964^{2}$. Between these twelve texts there are, for example, the type ATU 567 - the magic bird heart, and the tale about a man who searched immortality.

Among Sulkhan-Saba Orbeliani's collected fables in sibrdzne sitsruisa ("the wisdom of the lie") are some Georgian folktales such as ATU 56 - the fox and the bird, ATU 61 - the fox as confessor, ATU 667 - the foster-son of the forest ghost, ATU 670 - knowing of animal language etc. ${ }^{3}$.

Some Georgian fairytales were published in the Russian periodical press of the nineteenth century: Tiflisskie vedomosti ("Tbilisi news") sqq. 1828, and Kavkaz ("Caucasus") sqq. 1846. The Caucasus - one of the politically most restless regions of the Russian Empire, became the object of many ethnographic studies in the 1840s which were driven by imperialist motivations.

The systematic collecting of Georgian folklore started in the 1860s.

The growth of the "Georgian National Liberation Movement", as in other East European regions under the control of great empires, fostered literary and scientific interest in the presentation of folklore. Nationalists used old documents and folklore research to legitimise the allegedly historic roots of their fatherland. Folklore sources included: folk tales, epic stories and ballads,

\footnotetext{
2 M. TAMARASHVILI, Istoria katolikobisa kartvelta shoris (History of Catholicism between Georgian), Tbilisi, 1902; E. VIRSALADZE, "Masalebi kartuli folkloris istoriisatvis" (Materials for history of Georgian Folklore), Literaturuli driebani (1948), p. 363-383; M. CHIKOVANI, "XVII saukuneshi chacerili kartuli zgaprebi" (Georgian folktales written in 17th century), Mravaltavi 1 (1964), p. 61-207.

3 S.S. Orbeliai, La vérité du mensogne, Trad. G. Bouatchidzé, Paris, 1984; S.S. ORBELIAI, Die Weisheit der Lüge, Berlin, 1973.
} 
legends and memorabilia connected with heroes of the national history. These intensified claims of national authenticity, which in turn heightened concerns for their preservation. In 1860-ies, Georgian writers like Ilia Tchavtchavadze (1837-1907) and Akaki Tsereteli (1840-1915) played the most important role in initiatives to protect Georgian cultural Heritage, with the support of the "Society for the Popularization of Reading and Writing in Georgia" and the "Society for History and Ethnography of Georgia".

\section{Georgian folktales published since 1890}

Lado Aghniashvili (1860-1904) published the first edited volume of Georgian folktales in $1890^{4}$. Further collections between 1890-1930 were published by B. Nizharadze (1893) ${ }^{5}$, S. Merkviladze $(1903)^{6}$, T. Razikashvili $(1909)^{7}$, E. Takaishvili $(1919)^{8}$ and others. The Russian periodicals such as Sbornik materialov dlja opisania mesnostej i plemen kavkaza ("Collection of materials for the description of the locations and tribes in Caucasus") brought additional folklore material into the public domain between 18811915. Georgian folktales published in English, German, French, Hungarian, Bulgarian, Czech (Wardrop 1894; Papashvily 1946; Dirr 1922; Fähnrich 1980; Baye 1900; Istvánovits 1958, Minčeva 1957; Jedlička 1949) $)^{9}$.

Georgian ethnographers began systematic field research in the 1930s. Georgian folklorist and literary scholar Vakhtang Kotetishvili (1893-1937) established folkloristics as a new discipline at the Tbilisi State University in 1927 and a folkloristic department in the State Museum of Georgia in 1932. He also set up two folklore archives, namely: "Folklore Archive at the Institute of Georgian Literature" and "Archive at the Folklore State Centre of Georgia". In 1967 Tbilisi State University became the home of the "Folklore Archive". Beside Georgian cultural heritage, these archives preserve the records of other ethnic minorities like Georgian Jews, Abkhazians, Ossetians and others.

\footnotetext{
${ }^{4}$ L. Aghniashvili, Kartuli zghaprebi (Georgian fairytales), Tbilisi, 1890.

${ }^{5}$ B. NIZHARADZE, Svanuri zghaprebi (Svan fairytales), Kutaisi 1893.

${ }^{6}$ S. MERKVILADZE, Khalkhuri aghaprebi (folk tales), Kutaisi, 1903.

7 T. RAZIKASHVILI, Khalkburi zghaprebi kartlshi shekerebili folk tales collected in Kartli), Tbilisi, 1909; IBID., Khalkhuri zghaprebi kakhetsa da pshavshi shekrebili (folk tales collected in Kakheti and Pshavi), Tbilisi, 1909.

${ }^{8}$ E. TAKAISHVILI (ed.), Khalkhuri sitkviereba (Folklore), Tbilisi, 1919.

9 M. WARdrop (ed.), Georgian Folk Tales, London, 1894; G. and H. Papashvili, Yes and No Storys. A Book of Georgian Folk Tales, New York, 1946; A. DIRR, Kaukasische Märchen, Jena, 1922; H. FÄHNRICH (ed.), Georgische Märchen, Leipzig, 1980; B.J. BAYE, La Beauté. Légende Géorgienne, Paris, 1900; M. IstVANOVITS, A király meg a pacsirta, Budapest, 1958; D. MinČEVA, Gruzinski narodni prikąki, Sofija, 1957 ; J. JEDLIČKA, Gruqinské pohádky, Praha, 1949.
} 


\section{The connection between the literature and oral folklore}

Surviving chronicles and other written sources fortunately give an impression of how folk tales were performed. At the beginning of the eighteenth century, the Georgian scholar Vakhushti Bagrationi (1696-1757) recorded information concerning the proper oral narration of fairytales, fables and poetry (Bagrationi 1886 ${ }^{10}$. Bernarde from Napoli criticised in his writing that Georgians preferred to read Rostomiani, Bezhaniani (Georgian versions of Persian poem Săh-Nāme by Firdausi) and other worldly books, rather than religious literature ${ }^{11}$. The Georgian public liked especially the twelfth century poet Shota Rustaveli. His poem Vepkhistkaosani ("The Man in the Panther Skin") was the most popular book in Georgia during the late Middle Ages. Folklore Versions of Vepkhistkaosani can be found in various regions of Georgia and in North Caucasus as well.

\section{The genres of Georgian folklore}

The geographical position of Georgia, a region lying between East and West, formed a natural melting pot of cultures.

Georgian oral folklore contains various genres covering animal tales, magic tales, novelistic tales, realistic tales, religious tales, legends, anecdotes, jokes, cumulative tales, myths, etiological tales, ballads, poems, proverbs, riddles and others. There are of some regional variations. Fairytales are very popular in the lowlands but the inhabitants in the high mountain regions of Georgia prefer epic cycles and myths.

The Georgian folktales feature numerous cases where the plot of the fairytale is based upon myth but the myth has not been transformed into a fairytale. The majority of these examples comes from the mountain regions of Georgia, suggesting that mythical thought was more prevalent in these regions than in the plains.

\section{The mythological themes of Georgian fairytales}

Georgian fairytales' themes are a blend of exo- and indigenous well as international and original. International themes include

\footnotetext{
${ }^{10}$ V. Bagrationi, Kilila da Damana (Kilila and Dimna), Tbilisi, 1886.

11 E. VirSALADZE, "Zghapari” (Fairytale), in Kartuli khalkhuri poeturi shemokmedeba (Georgian folk poetry), Tbilisi, 1960, p. 366-369.
} 
ATU 300-399 - supernatural adversaries, ATU 400-459 supernatural or enchanted wife (husband) or other relative, ATU 460-499 - supernatural tasks ATU 460-499, ATU 500-559 supernatural helpers and helpful animals, ATU 560-649 magic objects, ATU 650-699 - supernatural power or knowledge.

Stability and continuity of the tradition enable folklorists and ethnologists to connect folk tales written down in the $19^{\text {th }}$ and $20^{\text {th }}$ centuries with such historical periods that have no written sources at all. We do not know how folk tales were told in ancient times. It is difficult to answer this question. Instead, there are many motifs and mythologems which constitute the building material for the folk tales.

Plots, depicted in archaic art found within the territorial boundaries of Georgia, are discussed by investigators in view of ritual and mythological aspects. Archaeological materials also are used by folklorists, for the reconstruction of the Georgian mythology. They have helped to identify stylistic emphases in folk tales. For example, Georgian folklorist Mikheil Chikovani attempted to reconstruct the Georgian folk epic Amirani with the help of archaeological materials ${ }^{12}$.

Georgian ethnologist Irakli Surguladze showed a similar interest in the topic of correlation of the archaeological materials and folk tales ${ }^{13}$.

Georgian historian Manana Khidasheli drew parallels between the plot depicted on a bronze belt found in Georgia (ca. seventh century BC). The belts displayed various motifs on the girdle, including the fight between a bird and a snake. The bird and the snake on the bronze girdle are shown opposite each other. M. Khidasheli referred to this image as the "Scene of the fight between a snake and a bird" and linked it with motifs from Georgian folk tales and a Sumerian epos ${ }^{14}$.

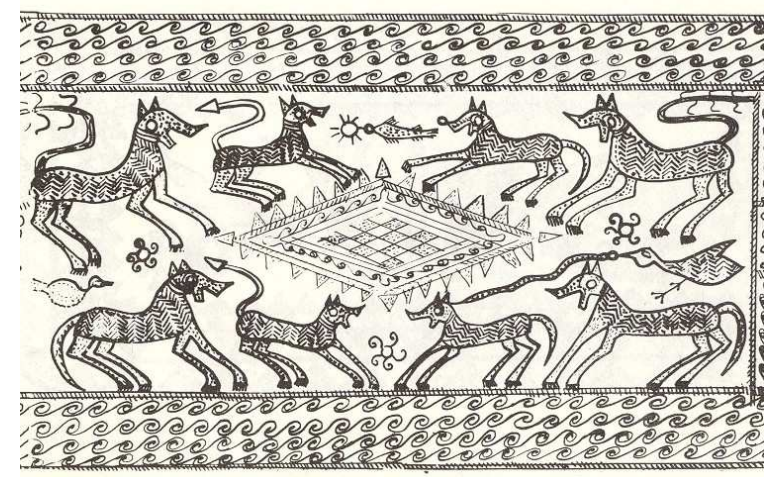

1. Detail of the bronze belt, found in Georgia, ca. $7^{\text {th }}$ century BC

\footnotetext{
12 M. ChIKovani, Mijatchunli Amirani (Enchained Amirani), Tbilisi, 1947, p. 57-88.

13 I. SURGULADZE, Kartuli khalkhuri ornamentis simbolika (The symbolism of Georgian folk ornament), Tbilisi 1986, p. 107-108.

${ }_{14}$ M. KHIDASHELI, Tsentraluri amierkavkasiis grapikuli khelovneba adreul rkinis khanashi (The graphic art of the Central Caucasus in the earliest iron period), Tbilisi, 1982, p. 65.
} 


\section{The supernatural helpers and antagonists in Georgian fairytales}

\section{Zoomorphic figures}

The most common 'helpful animals' in Georgian fairytales are the horse, the deer, the bullock, the ram (sheep), the fox and the fish (further helpful animals can also be the wolf, the bear, the eagle, the dog and the cat). Many Georgian fairytales feature a supernatural being with an ambivalent character: the gveleshapi ("snake-whale") which represented dragon. In general, the word dragon in the folklore of the peoples of Europe (as well as its variants such as German Drache, English dragon) are derived from the Latin word draco, which means 'snake'.

The gveleshapi can either be an enemy of the hero or a friend. The snake exhibits two primary functions in Georgian folk tales. In the fairytale of the ATU 301 type the dragon is an adversary of the hero, and in the tale of ATU 425 type, it is a supernatural spouse. The type of the tale in which the snake and the bird are both present together is ATU $301^{15}$.

In many Georgian fairytales the hero goes down into the underworld, rescues the king's daughter from the captivity of the snake and returns to earth. The bird paskunji is his helper.

A paskunji (Lat. Neophron percnopterus, Eng. Egyptian vulture, common also in Georgia) is a very important character in Georgian folk tales. In Georgian fairytales paskunji belongs to the range of fantastic creatures.

The paskunji and the gveleshapi represent the couple that will necessarily be present in tales of the hero's adventures in the underworld.

In Georgian folk tales the meeting point of the opposing gveleshapi and paskunji is the tree where the paskunji has a nest. This motif preserves the oldest myths of the cosmic tree (the World Tree, Iggdrassit). According to the Georgian mythological tradition, the centre of the Universe is occupied by a poplar tree emitting myrrh, and in ancient Georgian ornaments the motif of the World Tree is abundant.

15 E. Gogiashvili, "The Christian and Pre-Christian Symbolism of Dragon (gveleshapi) in Georgian Folktales (dragon-antagonist and dragonspouse)", In Knowledge and Symbol, Popular Belief and Custom. Collection of Essays. The Second International Conference in the framework of the promotion of the UNESCO Convention for the Safeguarding of Intangible Cultural Heritage, Yerevan, 2007, p. 5869. 


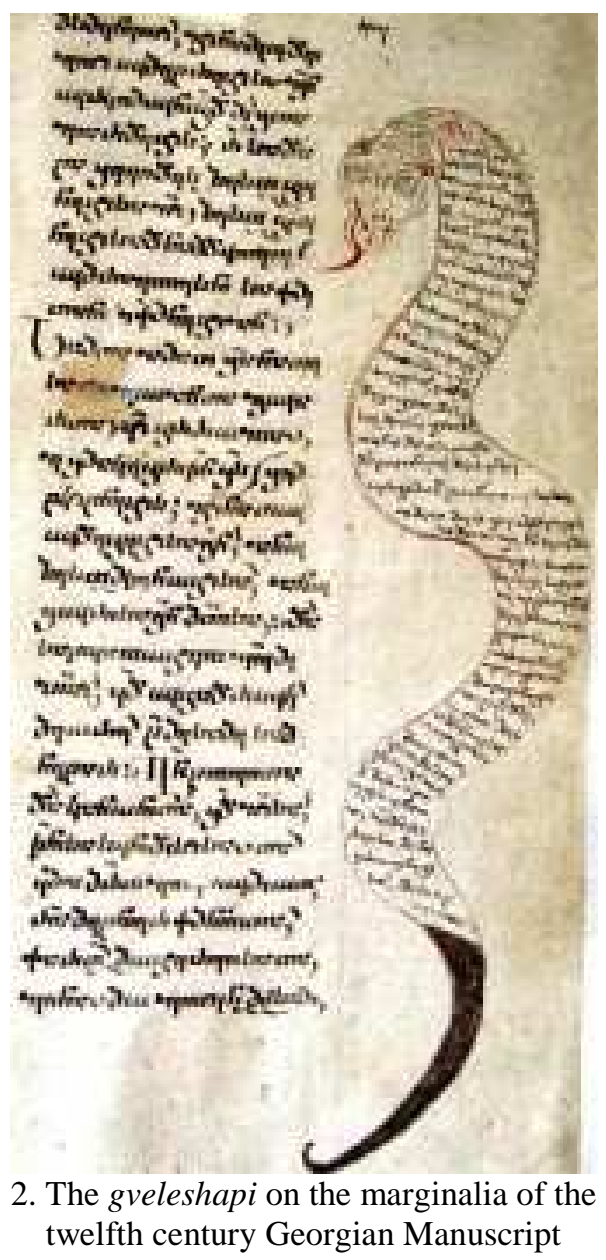

Both the snake and the bird possessed ambivalent qualities the bird dwells in the lower world, and the snake can move on the ground and fly. This topos can be found in various folk tales around the world. In Georgian material, like the tales of the tree brothers, winged snakes in the underworld are rare. In Georgian folk tales the gveleshapi, defeated by the hero, has no wings.

\section{Anthropomorphic figures}

One of the important supernatural beings in Georgian fairytales is the giant called devi, a representative of the principle of evil, but with certain limitations, neither incorporeal nor immortal, but half demon half man, i.e. an unclean spirit in the form of a giant. He is subject to death even a man can kill, cheat and terrify him; he can marry a woman. His nature is also ambivalent like the snake: sometimes he is an enemy but sometimes a friend of the hero.

There are various kinds of witches in Georgian folk tales. One of them is devis deda "the mother of the devi". She is dangerous but if the hero speaks politely and respectfully to her, she will help him. Further witches are ali - the beautiful women with golden hairs living in water, in forest or in huge rock caves, rokapi- the ugly woman with demonical character, and dedaberi - the old wise 
woman. All of them have an ambivalent nature. Whether they show their positive or negative power depends on the hero's behaviour.

\section{Love and Transformation}

The marriage of the hero with the supernatural being is one of the most popular fairytale motifs in the world. In Georgian folk tales the motif of enchanted wife or husband reoccur. The Georgian fairytale "The Frog's skin" is one of the examples of the fairytale type 'enchanted wife'. The journeys which happen in this fairytale are significant because of their extraordinary character. First, the hero goes to the magic lake where he finds his frog-wife and then, from time to time, visits his parents-in-law to ask for their help. Secondly, the hero makes a long journey through the underworld in the kingdom of deaths and returns successfully. His transport is a magic ram which can move in all terrains, including hell. On the way the hero meets some strange characters like a man and woman on a bullock's skin, which is too small for the both; a man and woman sitting on an axe-handle, not afraid of falling; a priest feeding cattle, whose beard spread over the ground; and the cattle, instead of eating grass, fed on the priest's beard. When the hero asks these people what is the meaning of this, they just reply "I have seen many pass by like thee, but none has returned. When thou comest back I shall answer thy question".

This fairytale grabs attention with the ancient motifs which are both pagan and Christian. The magic ram with twisted horns issuing a flame of fire, seems like very pre-Christian symbol. The hell through which he passes, invokes images from the Christian religion.

\section{Conclusion}

The interaction between mythical and religious aspects of the fairytales is very interesting. On top of their mythical foundations, many characteristics common to Christian thought structures appear in magic fairytales. Georgian fairytales include elements of the nature-based religions of ancient times while Christian religion is also reflected in them. 
Christianity (as state religion since 337 ) has had a prolonged influence on Georgian culture. Therefore, Christianity is reflected in Georgian folktales. ${ }^{16}$

The Christian and pre-Christian aspects of Georgian fairytales cannot be separated from one another, nor are they mutually exclusive. In the same fairytale it is common to find mythic traditions, as well as a later religious worldview. It is also possible to determine the modes of thought of a society through its fairytales. There are various examples of this in Georgian folk literature: 1 . when the fairytale is only mythological; 2 . when the Christian features in the fairytale are present along with the mythological, but the entire fairytale in not yet fully Christianized; 3. when the mythological motifs have a Christian content. However, there are no cases in which a fairytale exists only in the Christian tradition, without any traces of the mythological. The fairytale below is one of the examples of this.

\section{Appendix}

\section{The Frog's Skin ${ }^{17}$}

There were once three brothers who wished to marry. They said: 'Let us each shoot an arrow, and each shall take his wife from the place where the arrow falls.' They shot their arrows; those of the two elder brothers fell on noblemen's houses, while the youngest brother's arrow fell in a lake. The two elder brothers led home their noble wives, and the youngest went to the shore of the lake. He saw a frog creep out of the lake and sit down upon a stone. He took it up and carried it back to the house. All the brothers came home with what fate had given them; the elder brothers with the noble maidens, and the youngest with a frog.

The brothers went out to work, the wives prepared the dinner, and attended to all their household duties; the frog sat by the fire croaking, and its eyes glittered. Thus they lived together a long time in love and harmony.

At last the sisters-in-law wearied of the sight of the frog; when they swept the house, they threw out the frog with the dust. If the youngest brother found it, he took it up in his hand; if not, the frog would leap back to its place by the fire and begin to croak. The noble sisters did not like this, and said to their husbands: 'Drive this frog out, and get a real wife for your brother.' Every

16 E. Gogiashvili, "The Christian Symbolism of Animal Figures in Georgian Folktales according to the Manuscript of 12th century", Fabula. Journal of Folktale Studies 47 (2006), p. 65-78.

17 From the collection: Georgian Folk Tales, transl. by M. WARDROP, London, 1894. 
day the brothers bothered the youngest. He replied, saying: "This frog is certainly my fate, I am worthy of no better, I must be faithful to it.' His sisters-in-law persisted in telling their husbands that the brother and his frog must be sent away, and at last they agreed.

The young brother was now left quite desolate: there was no one to make his food, no one to stand watching at the door. For a short time a neighbouring woman came to wait upon him, but she had no time, so he was left alone. The man became very melancholy.

Once when he was thinking sadly of his loneliness, he went to work. When he had finished his day's labour, he went home. He looked into his house and was struck with amazement. The sideboard was well replenished; in one place was spread a cloth, and on the cloth were many different kinds of tempting viands. He looked and saw the frog in its place croaking. He said to himself that his sisters-in-law must have done this for him, and went to his work again. He was out all day working, and when he came home he always found everything prepared for him.

Once he said to himself: 'I will see for once who is this unseen benefactor, who comes to do good to me and look after me.' That day he stayed at home; he seated himself on the roof of the house and watched. In a short time the frog leaped out of the fireplace, jumped over to the doors, and all round the room; seeing no one there, it went back and took off the frog's skin, put it near the fire, and came forth a beautiful maiden, fair as the sun; so lovely was she that man could not imagine anything prettier. In the twinkling of an eye she had tidied everything, prepared the food and cooked it. When everything was ready, she went to the fire, put on the skin again, and began to croak. When the man saw this he was very much astonished; he rejoiced exceedingly that God had granted him such happiness. He descended from the roof, went in, caressed his frog tenderly, and then sat down to his tasty supper.

The next day the man hid himself in the place where he had been the day before. The frog, having satisfied itself that nobody was there, stripped off its skin and began its good work. This time the man stole silently into the house, seized the frog's skin in his hand and threw it into the fire. When the maiden saw this she entreated him, she wept--she said: 'Do not burn it, or thou shalt surely be destroyed' -but the man had burnt it in a moment. 'Now, if thy happiness be turned to misery, it is not my fault,' said the sorrow-stricken woman.

In a very short time the whole country-side knew that the man who had a frog now possessed in its place a lovely woman, who had come to him from heaven.

The lord of the country heard of this, and wished to take her from him. He called the beautiful woman's husband to him and said: 'Sow a barnful of wheat in a day, or give me thy wife.' When 
he had spoken thus, the man was obliged to consent, and he went home melancholy.

When he went in he told his wife what had taken place. She reproached him, saying: 'I told thee what would happen if thou didst burn the skin, and thou didst not heed me; but I will not blame thee. Be not sad; go in the morning to the edge of the lake from which I came, and call out: "Mother and Father! I pray you, lend me your swift bullocks"--lead them away with thee, and the bullocks will in one day plough the fields and sow the grain.' The husband did this.

He went to the edge of the lake and called out: 'Mother and Father! I entreat you, lend me your swift bullocks today.' There came forth from the lake such a team of oxen as was never seen on sea or land.

The youth drove the bullocks away, came to his lord's fields, and ploughed and sowed them in one day.

His lord was very much surprised. He did not know if there was anything impossible to this man, whose wife he wanted. He called him a second time, and said: 'Go and gather up the wheat thou hast sown, that not a grain may be wanting, and that the barn may be full. If thou dost not this, thy wife is mine.'

'This is impossible,' said the man to himself. He went home to his wife, who again reproached him, and then said: 'Go to the lake's edge and ask for the jackdaws.'

The husband went to the edge of the lake and called out: 'Mother and Father! I beg you to lend me your jackdaws to-day.' From the lake came forth flocks of jackdaws; they flew to the ploughed ground, each gathered up a seed and put it into the barn.

The lord came and cried out: 'There is one seed short; I know each one, and one is missing.' At that moment a jackdaw's caw was heard; it came with the missing seed, but owing to a lame foot it was a little late.

The lord was very angry that even the impossible was possible to this man, and could not think what to give him to do.

He puzzled his brain until he thought of the following plan. He called the man and said to him: 'My mother, who died in this village, took with her a ring. If thou goest to the other world and bringest that ring hither to me, it is well; if not, I shall take away thy wife.'

The man said to himself: 'This is quite impossible.' He went home and complained to his wife. She reproached him, and then said: 'Go to the lake and ask for the ram.' The husband went to the lake and called out: 'Mother and Father! give me your ram (Schafbock - E. G.) to-day, I pray you.' From the lake there came forth a ram with twisted horns; from its mouth issued a flame of fire. It said to the man: 'Mount on my back!' 
The man sat down, and, quick as lightning, the ram descended towards the lower regions. It went on and shot like an arrow through the earth.

They travelled on, and saw in one place a man and woman sitting on a bullock's skin, which was not big enough for them, and they were like to fall off. The man called out to them: 'What can be the meaning of this, that this bullock skin is not big enough for two people?' They said: 'We have seen many pass by like thee, but none has returned. When thou comest back we shall answer thy question.'

They went on their way and saw a man and woman sitting on an axe-handle, and they were not afraid of falling. The man called out to them: 'Are you not afraid of falling from the handle of an axe?' They said to him: 'We have seen many pass by like thee, but none has returned. When thou comest back we shall answer thy question.'

They went on their way again, until they came to a place where they saw a priest feeding cattle. This priest had such a long beard that it spread over the ground, and the cattle, instead of eating grass, fed on the priest's beard, and he could not prevent it. The man called out: 'Priest, what is the meaning of this? why is thy beard pasture for these cattle?' The priest replied: 'I have seen many pass by like thee, but none has returned. When thou comest back I shall answer thy question.'

They journeyed on again until they came to a place where they saw nothing but boiling pitch, and a flame came forth from it-and this was hell. The ram said: 'Sit firmly on my back, for we must pass through this fire.' The man held fast, the ram gave a leap, and they escaped through the fire unhurt.

There they saw a melancholy woman seated on a golden throne. She said: 'What is it, my child? what troubles thee? what has brought thee here?' He told her everything that had happened to him. She said: 'I must punish this very wicked child of mine, and thou must take him a casket from me.' She gave him a casket, and said: 'Whatever thou dost, do not open this casket thyself, take it with thee, give it to thy lord, and run quickly away from him.'

The man took the casket and went away. He came to the place where the priest was feeding the cattle. The priest said: 'I promised thee an answer; hearken unto my words. In life I loved nothing but myself, I cared for nought else. My flocks I fed on other pastures than my own, and the neighbouring cattle died of starvation; now I am paying the penalty.'

Then he went on to the place where the man and woman were sitting on the handle of the axe. They said: 'We promised thee an answer; hearken unto our words. We loved each other too well on earth, and it is the same with us here.' 
Then he came to the two seated on the bullock skin, which was not big enough for them. They said: 'We promised thee an answer; hearken unto our words. We despised each other in life, and we equally despise each other here.'

At last the man came up on earth, descended from the ram, and went to his lord. He gave him the casket and quickly ran away. The lord opened the casket, and there came forth fire, which swallowed him up. Our brother was thus victorious over his enemy, and no one took his wife from him. They lived lovingly together, and blessed God as their deliverer. 